\title{
Measurement of company effectiveness using analytic network process method
}

\section{Meritve uspešenosti podjetja s pomočjo metode analitičnega mrežnega procesa}

\author{
Janjić Goran ${ }^{1, *}$, Tanasić Zorana ${ }^{1}$, Kosec Borut ${ }^{2}$ \\ ${ }^{1}$ Faculty of Mechanical Engineering, University of Banja Luka, Banja Luka, Bosnia-Herzegovina, \\ ${ }^{2}$ Faculty of Natural Sciences and Engineering, University of Ljubljana, Slovenia \\ *goran.janjic@unibl.rs
}

\begin{abstract}
The sustainable development of an organisation is monitored through the organisation's performance, which beforehand incorporates all stakeholders' requirements in its strategy. The strategic management concept enables organisations to monitor and evaluate their effectiveness along with efficiency by monitoring of the implementation of set strategic goals. In the process of monitoring and measuring effectiveness, an organisation can use multiple-criteria decision-making methods as help. This study uses the method of analytic network process (ANP) to define the weight factors of the mutual influences of all the important elements of an organisation's strategy. The calculation of an organisation's effectiveness is based on the weight factors and the degree of fulfilment of the goal values of the strategic map measures. New business conditions influence the changes in the importance of certain elements of an organisation's business in relation to competitive advantage on the market, and on the market, increasing emphasis is given to non-material resources in the process of selection of the organisation's most important measures.
\end{abstract}

Key words: effectiveness, balanced scorecard, strategy management, analytic network process

\section{Povzetek}

Trajnostni razvoj organizacije se ovrednosti preko tega, kako uspešno je v svoji strategiji razvoja vključila potrebe vseh zainteresiranih strani. Pri tem ji strateški koncept upravljanja omogoča, da spremlja in ocenjuje svojo uspešnost in učinkovitost na podlagi uspešnosti izvajanja zastavljenih strateških ciljev. Analitikom so pri tem v pomoč statistične metode za določanje na podlagi skupnega vpliva različnih kriterijev. V tem delu smo za določitev kazalcev skupnih vplivov vseh pomembnih elementov strategije organizacije uporabili metodo analitičnega mrežnega procesa. Izračun ocene uspešnosti temelji na faktorjih vpliva in stopnji izpolnitve strateškega plana. Novi pogoji poslovanja, pa v kolikor želimo konkurenčno prednost na trgu, zahtevajo spremembo v hierarhiji pomembnosti nekaterih elementov poslovanja organizacije. V poslovnem svetu je tako v procesu izbora najpomembnejših ukrepov in ciljev vse več poudarka na nematerialnih sredstvih.

Ključne besede: uspešnost podjetja, uravnoteženi sistem kazalcev, proces strateškega planiranja, analitični mrežni proces 


\section{Introduction}

Changes in the traditional concept of organisation management have taken place due to the changes in business conditions. Application of new strategic management concepts cause changes in the focus from process and functions to strategy. The process of defining a strategy consists of defining strategic goals (SGs) and measures for its implementation. New business conditions ask organisations to take into consideration all necessary external factors and information in processes such as planning, decision making, monitoring and control of processes, and achievement of improvement in projects. In order to survive, grow, and develop, in addition to being efficient (which is a goal of traditional management concept), organisations also have to be effective in given conditions by directing all their efforts towards achievement of SGs ${ }^{1}$. Organisations have to create efficient strategic control mechanisms if they want to implement their strategies successfully [1]. The future of the organisation is increasingly based on the monitoring of non-financial performances of the organisation, which represents a significant change compared to the traditional management concept. According to Stewart, editor of Harvard Business Review Magazine, 'the most important of all property is "soft" property, like skills, capability, expertise, culture, loyalty, etc. This is knowledge property - intellectual capital - and it defines success or failure of an organisation' [2].

The sustainable development of an organisation could be seen as a source of constant satisfaction of all its stakeholders and is something that all organisations should aspire to achieve.

\section{Methods for measuring effectiveness of organisation}

Organisations can use several different methods for measuring effectiveness, such as Balanced Scorecard (BSC), Six Sigma, European Foundation for Quality Management, Malcolm

1 Peter Drucker gave the definition of effectiveness and efficiency in his book The Effective Executive (1966). According to him, "Efficiency is doing things right; effectiveness is doing the right things".
Baldrige Award Criteria, Economic Value Added (EVA), Performance Prism and others. Research shows that of the existing methods for measuring effectiveness, $>60 \%$ of the most successful world organisations use the BSC [3].

Based on strategic analysis, defined vision and the mission, a company should identify the critical factors of success and the measurement characteristics (measures - performance) within all chosen perspectives. Critical success factors (CSFs) or generators of performances are all those factors, which if fulfilled, enable a company to reach set SGs. When choosing perspectives, the most frequently used is the 'Kaplan and Norton Concept', which recommends the use of perspective of customer, internal processes, learning and growth, and financial perspective. Nevertheless, every company has to start from its own specific situation, while choosing the necessary perspectives. According to the recommendation of the authors of the given concept, the four perspectives should be seen as the "model not mould" [4].

For all success factors within a given set of perspectives, organisation should define at least one measure that can be expressed by a numeric value or attribute. Measures can be described as standards that can be quantified and used for performance valuation in relation to expected results. For each measurement characteristic, there are a description and frequency of measurements, measuring tool, and target values (limits) that should serve for comparison with the measured value. The CSF is reached when all its characteristics are within the set limits. After choosing CSFs and measures from all perspectives, all their mutual relationships within certain perspectives, as well as relationships between factors of success and measures that are placed in different perspectives, should be revealed. Relationships are represented by a strategic map that provides a graphical display of everything a company has to do in every set perspective in order to implement its strategy. Figure 1 shows the strategic map of electric power organisation: ZP 'Elektrokrajina' Banja Luka.

\section{The Analytic Network Process method}

The Analytic Network Process (ANP) method was developed by Thomas Saaty. This method enables modelling of the functional interaction 


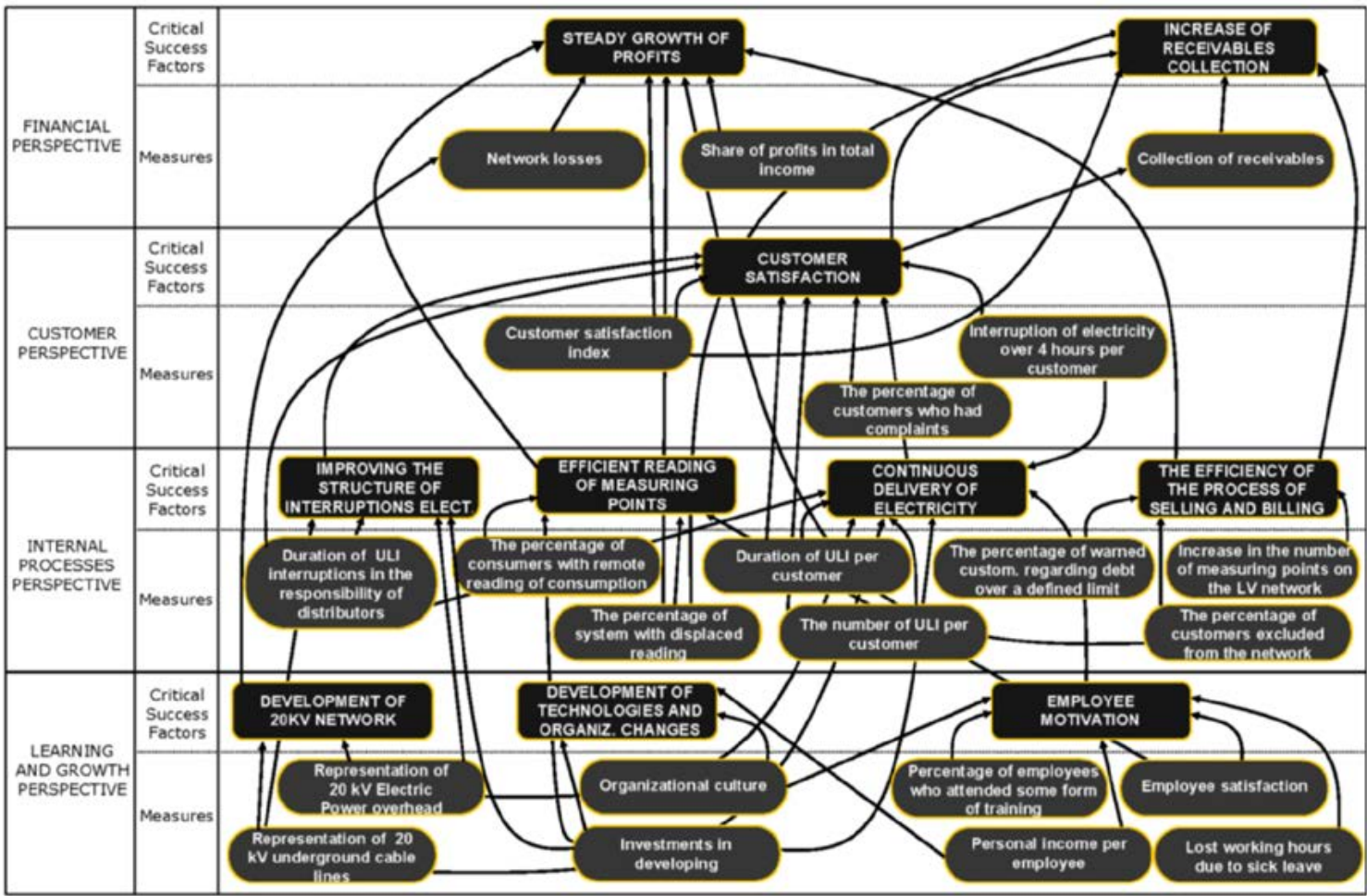

Figure 1: Strategic map of ZP'Elektrokrajina' Banja Luka Company.

of criteria and alternatives in a model. Network dependency of elements contributes to better modelling of realistic problems that are, in most cases, of non-linear nature. The network is the so-called feedback structure that contains components (clusters) and elements (knots) within components, as well as loops and arcs that connect the components of the network. The main element of the network is the cluster, and clusters consist of elements that are interconnected between and within clusters (Figure 2).

If the elements within clusters are interconnected (in relation to a feature), then the relation is called internal dependency of elements, and we show it with a loop (Figure 2: clusters $\mathrm{C}_{1}$ and $\mathrm{C}_{3}$ ). If the elements of different clusters are connected, then the connection is called external dependency. Thus, the arc of the $\mathrm{C}_{4}$ cluster in relation to the $\mathrm{C}_{2}$ cluster in Figure 2 represents external dependency of the elements of the $\mathrm{C}_{2}$ cluster in relation to the $\mathrm{C}_{4}$ cluster (in relation to a feature).

Source element is the element from which the arrow starts and influences the goal element, to which the arrow is directed, i.e., the goal element depends on the source element. If el-

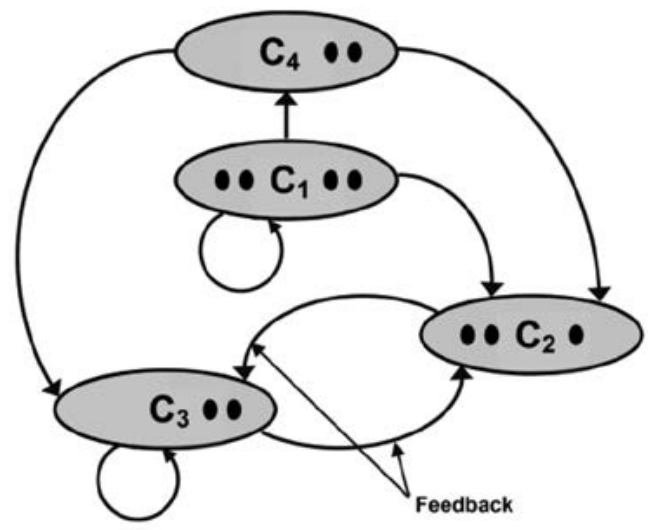

Figure 2: Non-linear network.

ements influence each other, the connection is called feedback connection (Figure 2: $\mathrm{C}_{2}$ and $\mathrm{C}_{3}$ ) [5]. Dependencies are created between elements, but for the sake of simplicity (e.g., in the Super Decisions software), they represent dependency between clusters.

In order to calculate the priorities of the elements of the ANP network, one must first show connections, explain the cluster and knot types in the ANP network, and calculate the neces- 
sary interdependency matrices. The overview of weight factors/priorities of all ANP model elements, resulting from the comparison of pair elements in accordance with their interdependencies, is given in the unweighted matrix.

In addition to the use of tools for calculating the level of implementation of SGs, multiple-criteria decision-making methods (ANP) can be used in the process of selecting measures.

\section{Setting of weight factors of ANP model elements}

The ANP is used to evaluate alternatives (representing the measures) with reference to CSFs that are directly related to SGs.

The ANP method enables both the modelling of functional interaction of criteria and alternatives in the model and the defining of the problem by modelling the influences between various network elements [5]. In order to calculate the priorities of the ANP elements, it is first necessary to show the links and explain the types of clusters and knots in the ANP network and calculate the necessary interdependency matrices.

During the development of the ANP model for the evaluation of the business system strategy implementation, equal importance is given to all perspectives, so that they do not have direct influence on the overall weight factors of measurement characteristics and CSFs in the implementation stage of SGs, thus obeying the balanced perspective criteria as well.

After the development of the strategic map, it is necessary to define the level (weight) of mutual influences of all strategic map elements. Thus, for each CSF in a strategic map, one should define the weight of the influence of measures that influence them, and for SGs, the weight of the influence of individual CSFs and the weight of the influence of SGs, on the achievement of overall business system strategy.

During the modelling of the strategic map, the elements' internal dependencies within perspectives show up (dependencies of CSFs and measures within one perspective), as well as external dependencies of perspectives (dependencies of CSFs and measures of different perspectives).
In addition to the listed dependencies, there are external dependencies of SGs and perspectives' success factors as well.

In order to define the weight of mutual influences of strategic map elements, it is necessary to create a non-linear network ANP model that is based on the strategic map, composed of clusters and elements. Afterwards, comparison of interdependent element pairs has to be made, and interdependency matrices for measures, CSFs and SGs have to be created. Established interdependency matrices are used to calculate the weight factors of strategic map elements. In the same way, weight factors of CSFs are defined according to their importance regarding the achieving of SGs, as well as the weight factors of SGs with reference to the implementation of the company strategy. The sum of relations' weight factors in one CSF or SG always equals one.

\section{Calculating the effectiveness of the company}

The strategic map shows all the cause-and-effect relations of the BSC elements. In developing the formula to calculate the level of implementation of the set strategy, one should first define the value of measures, i.e., elements in the strategic map. Strategic map elements can be dependent and independent (Figure 1). Independent elements do not depend on other elements and they can be seen as independent variables. The only independent variables on the strategic map are measures and they are used directly and indirectly to calculate the values of all other strategic map elements, which represent dependent variables. Dependent variables depend on one or more independent strategic map variables, i.e., the values of dependent variables are linear combinations of independent variables' values. Dependent variables are represented on the strategic map by CSFs, SGs, and the strategy. The formulae used to calculate the dependent elements of the strategic map are as follows.

The value of CSF $\left(\mathrm{m}_{\mathrm{CSF}}\right)$ is calculated using the following formula:

$\mathrm{m}_{\mathrm{CSFj}}=\sum \mathrm{m}_{\mathrm{ri}} \cdot \mathrm{k}_{\mathrm{ji}}$

The relative achieved value of the measure $\left(\mathrm{m}_{\mathrm{ri}}\right)$, the goal value being equal to the upper limit, is calculated using the following formula: 


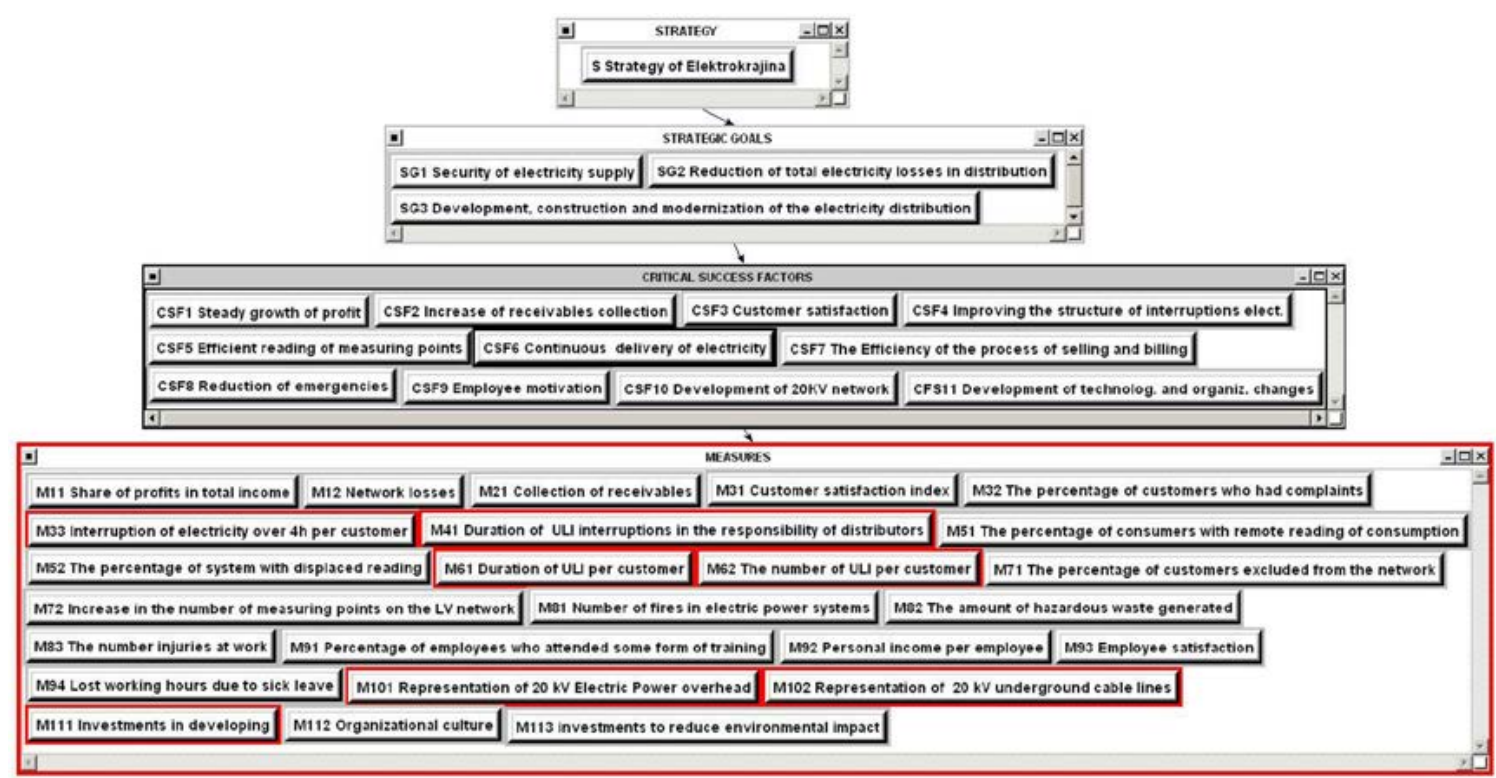

Figure 3: ANP model for the calculation of local priorities of strategic map elements in ZP "Elektrokrajina'.

$m_{r i}=\frac{m_{i}-L_{i}}{U_{i}-L_{i}}$

In the case of measures whose goal value equals the lower limit, the relative achieved value of the measure is calculated using the following formula:

$m_{r i}=\frac{U_{i}-m_{i}}{U_{i}-L_{i}}$

wherein $m_{i}$ is the measurement value, $L_{i}$ is the lower limit of $\mathrm{M}_{\mathrm{i}}$ measure, $\mathrm{U}_{\mathrm{i}}$ is the upper limit of $\mathrm{M}_{\mathrm{i}}$ measure, $\mathrm{k}_{\mathrm{ji}}$ is the weight factor of the influence of measure $M_{i}$ on the achievement of critical success factor $\mathrm{CSF}_{\mathrm{j}}$ (its value is given in the unweighted matrix).Value of $S G\left(m_{S G j}\right)$ is calculated using the following formula:

$\mathrm{m}_{\mathrm{SGj}}=\sum \mathrm{m}_{\mathrm{CSFi}} \cdot \mathrm{k}_{\mathrm{ji}}$

wherein $\mathrm{m}_{\mathrm{CSFi}}$ is the calculated value of CSF expressed as the relative sum of the measured value without its measure unit, $\mathrm{k}_{\mathrm{ji}}$ is the weight factor of $\mathrm{CSF}_{\mathrm{i}}$ influence on the achievement of strategic goal $\mathrm{SG}_{\mathrm{j}}$.

The value of achievement of the strategy of a business system $\left(\mathrm{m}_{\mathrm{s}}\right)$ is derived as follows:

$\mathrm{m}_{\mathrm{S}}=\sum \mathrm{m}_{\mathrm{SGi}} \cdot \mathrm{k}_{\mathrm{i}}$
The calculated value $\mathrm{m}_{\mathrm{s}}$, transformed in percentage, shows the percentage of achievement of the set business strategy system.

The detailed procedure of defining the formula to calculate the dependent elements of the strategic map are presented in a previous article [6].

\section{Evaluation of business effectiveness of an electricity distribution enterprise}

The validation of the methodology was performed for the electricity distribution enterprise 'Elektrokrajina' Banja Luka, which supplies electricity to 230,186 consumers. Based on the analysis of the external surroundings, SGs of the energy system, and internal processes, the top management of Elektrokrajina defined the following SGs:

- SG1. Electricity supply safety. Measures: providing new import-export and transit routes, marketing exchange, stable work system and support in crisis situations, the implementation of European Union Directive on electricity supply safety, promoting and introducing electricity consumption management measures, etc. In addition, the implementation of SGs related to the development of electric power system and loss reduction will have positive effect on supply safety.

- SG2. Reduction of total electricity losses during distribution. Measures: the reduction 


\begin{tabular}{|c|c|c|c|c|c|c|c|c|c|c|}
\hline \multicolumn{9}{|c|}{ ESuper Decisions Main Window: Elektrokrajina.mod: Unweighted Super Matrix } & \multicolumn{2}{|c|}{$-\square x$} \\
\hline & \multirow[b]{2}{*}{$\begin{array}{l}\text { Cluster } \\
\text { Node } \\
\text { Labels }\end{array}$} & \multicolumn{8}{|c|}{ CRITICAL SUCCESS FACTORS } & \\
\hline & & $\begin{array}{l}\text { CSF1 Steady } \\
\text { growth of } \\
\text { profit }\end{array}$ & $\begin{array}{l}\text { CSF2 Increase of } \\
\text { receivables } \\
\text { collection }\end{array}$ & $\begin{array}{l}\text { CSF3 } \\
\text { Customer } \\
\text { satisfaction }\end{array}$ & $\begin{array}{l}\text { CSF4 Improving } \\
\text { the structure of } \\
\text { interruptions elect. }\end{array}$ & $\begin{array}{l}\text { CSF5 Efficient } \\
\text { reading of } \\
\text { measuring points }\end{array}$ & $\begin{array}{l}\text { CSF6 Continuous } \\
\text { delivery of } \\
\text { electricity }\end{array}$ & $\begin{array}{l}\text { CSF7 The } \\
\text { Efficiency of the } \\
\text { process of seling } \\
\text { and blling }\end{array}$ & $\begin{array}{l}\text { CSF8 } \\
\text { Reduction of } \\
\text { emergencies }\end{array}$ & \\
\hline \multirow{8}{*}{$\begin{array}{l}\text { MEASU } \\
\text { RES }\end{array}$} & $\begin{array}{l}\text { M32 The percentage } \\
\text { of customers who } \\
\text { had complaints }\end{array}$ & 0.000000 & 0.000000 & 0.075032 & 0.000000 & 0.000000 & 0.000000 & 0.000000 & 0.000000 & \\
\hline & $\begin{array}{l}\text { M33 Interruption } \\
\text { of electricity over } \\
\text { 4h per customer }\end{array}$ & 0.000000 & 0.000000 & 0.164501 & 0.000000 & 0.000000 & 0.127359 & 0.000000 & 0.000000 & \\
\hline & $\begin{array}{l}\text { M41 Duration of ULI } \\
\text { interruptions in the } \\
\text { responsibility of } \\
\text { distributors }\end{array}$ & 0.000000 & 0.000000 & 0.151270 & 0.500000 & 0.000000 & 0.127359 & 0.000000 & 0.000000 & \\
\hline & $\begin{array}{l}\text { MS1 The percentage } \\
\text { of consumers with } \\
\text { remote reading of } \\
\text { consumption }\end{array}$ & 0.000000 & 0.000000 & 0.000000 & 0.000000 & 0.522245 & 0.000000 & 0.000000 & 0.000000 & \\
\hline & $\begin{array}{l}\text { MS2 The percentage } \\
\text { of system with } \\
\text { displaced reading } \\
\end{array}$ & 0.096150 & 0.166667 & 0.000000 & 0.000000 & 0.078091 & 0.000000 & 0.000000 & 0.000000 & \\
\hline & $\begin{array}{l}\text { M61 Duration of } \\
\text { ULI per } \\
\text { customer } \\
\end{array}$ & 0.000000 & 0.000000 & 0.164501 & 0.000000 & 0.000000 & 0.233809 & 0.000000 & 0.000000 & \\
\hline & $\begin{array}{l}\text { M62 The number } \\
\text { of uI per } \\
\text { customer }\end{array}$ & 0.000000 & 0.000000 & 0.102846 & 0.000000 & 0.000000 & 0.350576 & 0.000000 & 0.000000 & \\
\hline & $\begin{array}{l}\text { M71 The } \\
\text { percentage of } \\
\text { customers excluded } \\
\text { from the network }\end{array}$ & 0.059829 & 0.000000 & 0.000000 & 0.000000 & 0.000000 & 0.000000 & 0.142857 & 0.000000 & \\
\hline
\end{tabular}

Figure 4: Unweighted super matrix of the ANP model of 'Elektrokrajina.'

of unregistered usage by the reconstruction of ports and setting up of meters on facades or property boundaries, automation and remote control network, installation of electricity meters, enabling remote reading and consumption control, evaluation and reduction of the level of technical electricity losses, etc.

- SG3. Development, construction, and modernisation of electricity distribution. Measures: proper distribution network sizing to ensure reliable work and maintaining electricity quality parameters in accordance with the standards, constant planned investments in appliances and equipment (e.g., transformation of medium-voltage network into a system with one level of medium-voltage $20 \mathrm{kV}$ and one direct transformation 110/20 kV networks).

Figure 3 shows the ANP model with established interdependencies between strategic map elements. These interdependencies create comparison matrices and define which pairs of elements will be compared in defining their importance.
Figure 4 shows the unweighted matrix of all strategic map elements of ZP 'Elektrokrajina' Banja Luka Company in the Super Decisions program package. There are weight factors/ priorities of all ANP model elements in the unweighted matrix.

After the calculation of measurements priorities and the collection of their achieved values, calculated at prescribed time intervals, the 'relative achieved value of the measure' for 2008 and 2009 (Table 1) were calculated using formulas (2) and (3) and used for the calculation of the achievement of CSFs, SGs, and the strategy of the company (dependent measures).

Figure 5 shows a comparative review of the calculated values of the dependent elements of the strategic map (CSFs, SGs, and business system strategy) for 2009, calculated using formulas (1), (4), and (5).

A comparative review of the calculated values of the dependent elements of the strategic map (CSFs, SGs, and business system strategy) for 2008 and 2009 are given in Table 2.

Electricity distribution enterprise Elektrokrajina made significant improvement in the implementation of the SGs, especially the devel- 


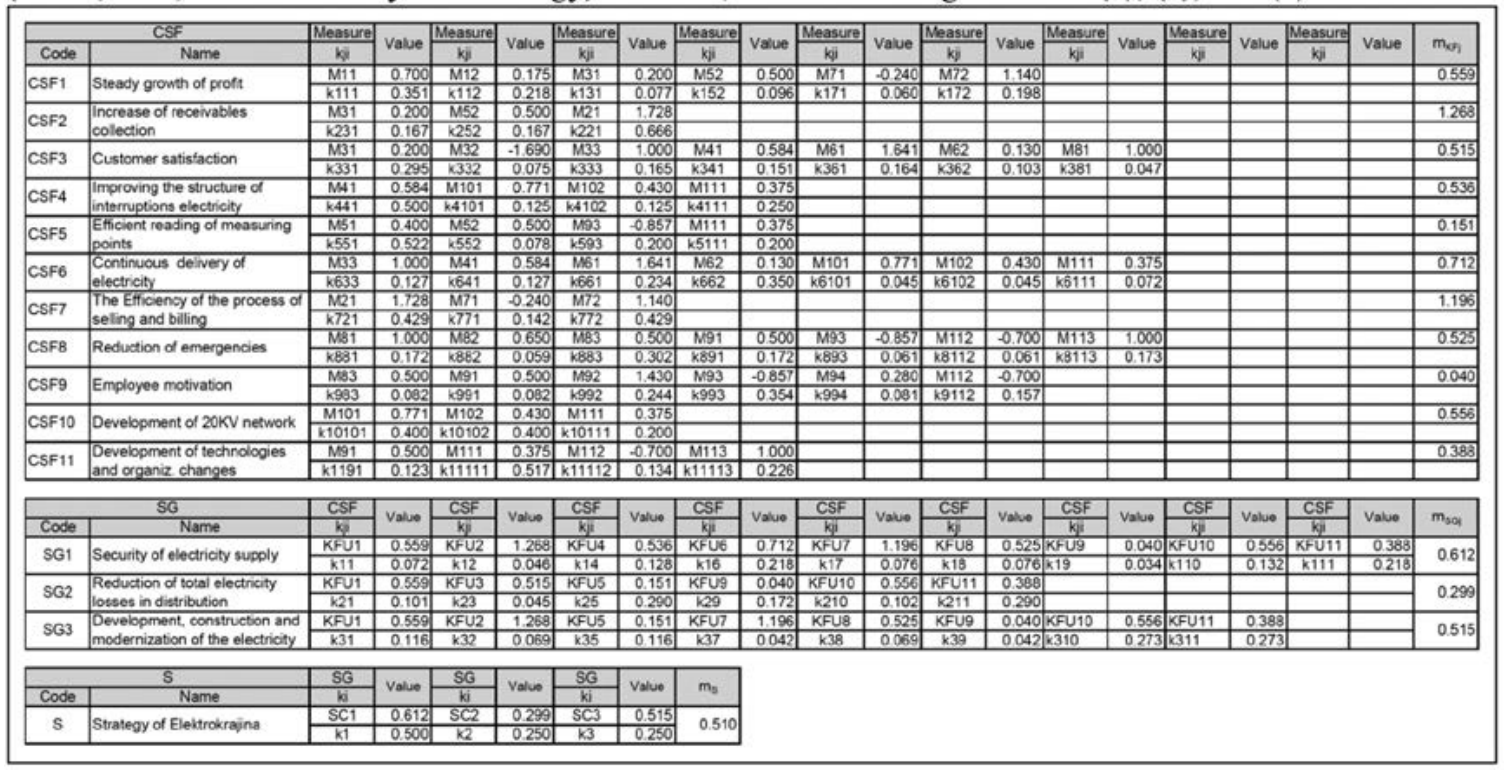

Figure 5: Calculated dependent measures' values for 2009.

Table 1: Measure description and relative achieved value

\section{CODE}

MEASURE

M61 Duration of unplanned long interruptions (ULI) per customer
MEASURING PERIOD

Quarterly

\begin{tabular}{cccc}
\hline MU & \multicolumn{4}{c}{ CALCULATION FORMULA } \\
\hline $\begin{array}{c}\text { min/ } \\
\text { customer }\end{array}$ & \multicolumn{4}{c}{ (sum (duration ULI $\times$ number of customers that experienced the supply interruption))/ } \\
total number of customers
\end{tabular}

Note: *Average yearly values.

Table 2: Review of achieved values of CSF and strategy for Elektrokrajina in 2008 and 2009

\begin{tabular}{cccc} 
& Element of strategic map & \multicolumn{2}{c}{ Achievement } \\
\hline Code & Name & $\mathbf{2 0 0 8}$ & $\mathbf{2 0 0 9}$ \\
\hline & STRATEGIC GOALS & $\mathrm{m}_{\mathrm{SGj}}$ & 0.612 \\
\hline SG1 & Security of electricity supply & 0.368 & 0.299 \\
\hline SG2 & Reduction of total electricity losses in distribution & -0.139 & 0.515 \\
\hline SG3 & Development, construction, and modernisation of the electricity \\
& distribution & 0.098 & $\mathrm{~m}_{\mathrm{S}}$ \\
\hline $\mathrm{S}$ & STRATEGY & 0.174 & 0.510 \\
\hline
\end{tabular}


opment, building, and modernisation of the electricity distribution system. Compared to 2008, achievement of strategy in 2009 was improved by $35.1 \%$. Improvement is evident in almost all elements of the strategic map, except in the field of electricity distribution continuity, which remained at the same level. In the future, the enterprise should work more on the decrease of total electricity losses in distribution.

\section{Conclusion}

An organisation can fulfil its goals of survival, growth, and development only with efficient management and timely defining of strategy and its successful implementation.

Successful implementation of a particular system's strategy is possible only by dividing it into its subsystems through the system of CSFs, measures, and goal values, whose level of implementation is monitored at defined time intervals. At the same time, one has to bear in mind that every established system is unique, and it is the result of a vision and mission of a concrete organisation.

The methodology presented in the article, which includes the ANP, enables more realis- tic business planning, as well as more realistic evaluation of business effectiveness, as presented in the case of a real organisation.

\section{References}

[1] Dess, G., Lumpkin, G., Eisner, A. (2007): Strategic Management: Text and Casis, McGraw-Hill Companies, $320 \mathrm{p}$.

[2] Niven, P. (2006): Balanced Scorecard step by step: Maximizing Performance and Maintaining Results, New Jersey: John Wiley \& Sons, 339 p.

[3] Silk, S. (1998): Automating the Balanced Scorecard, Management Accounting, 79 (11), pp. 38-44.

[4] Kaplan, R., Norton, D. (1996): The Balanced Scorecard: Translating Strategy Into Action. Boston: Harvard Business School Press, 322 p.

[5] Saaty, T., Vargas, L. (2006): Decison making with the Analytic Network Process: Economic, Political, Social and Technological Applications with Benefits, Opportunities, Costs and Risks. New York: Springer, p. 8.

[6] Janjić, G., Tanasić, Y., Kosec, B. (2015): The Methodology of Monitoring the Implementation of a Strategy in Electricity Distribution Enterprise. Transactions of Famena, XXXIX-3, pp. 61-75. 